https://doi.org/10.17816/MAJ191S147-48

\title{
CHARACTERISTICS OF ADAPTATIONAL REACTIONS AND MALIGNANT SPREAD IN TUMORS OF VARIOUS LOCATIONS
}

\author{
G.V. Zhukova, A.I. Shikhlyarova, U.M. Gaziev, M.S. Zinkovich, A.V. Snezhko, Yu.N. Lazutin, \\ A.N. Shevchenko, M.I. Bragina, A.I. Zhadobina \\ Rostov Research Institute of Oncology, Rostov-on-Don, Russia

\section{ХАРАКТЕРИСТИКИ АДАПТАЦИОННЫХ РЕАКЦИЙ И РАСПРОСТРАНЕННОСТЬ ОПУХОЛЕВОГО ПРОЦЕССА РАЗЛИЧНОЙ ЛОКАЛИЗАЦИИ}

\author{
Г.В. Жукова, А.И. Шихлярова, У.М. Газиев, М.С. Зинькович, А.В. Снежкко, Ю.Н. Лазутин, \\ А.Н. Шевченко, М.И. Брагина, А.И. Жадобина
}

ФГБУ «Ростовский научно-исследовательский онкологический институт» Минздрава России, Ростов-на-Дону

The character, intensity and quantitative indicator (QI) of general nonspecific adaptational reactions (AR) of the body were studied in patients with lung cancer (LC) or biliopancreatoduodenal cancer (BPDC) with various malignant spread. Poor AR characteristics were associated with the presence of metastases, but did not depend on the surgery volume. AR QI significantly differed depending on the metastatic status in patients with resectable LC receiving similar surgery treatment. AR QI in BPDC patients a day after radical pancreatoduodenal resection was higher than after bypass anastomosis. Thus, the studied AR characteristics demonstrated the state of systemic neuroimmune mechanisms of the nonspecific antitumor resistance of the body.

Keywords: malignant spread; adaptational reactions; metastasis; surgery.

Изучали характер и напряженность, а также балльную оценку (БО) общих неспецифических адаптационных реакций организма (АР) у пациентов, страдавших раком легкого (РЛ), а также у больных раком органов билиопанкреатодуоденальной зоны (БПДЗ), отличавшихся распространенностью опухолевого процесса. Было показано достоверное ухудшение характеристик АР при увеличении распространенности опухолевого процесса, но не объема оперативного вмешательства. У пациентов с резектабельным РЛ при аналогичном объеме хирургического вмешательства БО АР заметно различались в зависимости от наличия метастазов. У больных раком органов БПДЗ через сутки после радикальной панкреатодуоденальной резекции БО АР была выше, чем после формирования обходного анастомоза. Таким образом, исследованные характеристики АР отражали состояние системных нейроиммунных механизмов неспецифической противоопухолевой резистентности организма.

Ключевые слова: распространенность злокачественного процесса; адаптационные реакции; метастазы; оперативное вмешательство.

Introduction. The systemic regulation in cancer is poorly studied. A multilevel periodic system comprises general nonspecific adaptational reactions (AR) of the body, different in their nature and tension, associated with levels and ratio of the activity of various neuroendocrine and immune system components [1-3].

The purpose of the study was to reveal an association between AR characteristics and malignant spread in the lungs and biliopancreatoduodenal organs.

Material and methods. The study included 28 patients with lung cancer ( $\mathrm{LC}$ ) with various malignant spread: group (gr.) 1 - unresectable LC, chemoradiation treatment (10); gr. 2 - resectable metastatic LC, T2-3N1-2M0-1 (7); gr. 3 - resectable non-metastatic LC (11). Another cohort involved 32 patients with biliopancreatoduodenal cancer (BPDC) with different malignant spread and surgery volume: 19 patients - radical surgery (RS gr.), 13 patients - palliative surgical bypass (PS gr.). All patients were aged $30-70$ years, men to women ratio $-3: 2$.
The values of hematological parameters in patients were analyzed using an expert computer program "Antistress", and qualitative and quantitative (score) characteristics of AR were obtained [2]. The minimal quantitative indicator $(\mathrm{QI})-10-20-$ corresponded to the stress AR of "very low" reactivity levels (LRL, VLRL), while the maximal noted score -2800 - had the elevated activation AR of "moderate" reactivity levels (MRL) and was associated with the most balanced neuroimmune regulation in the studied patients. Statistical processing of results was performed using the t-test, Wilcoxon test and the fractional estimates.

Results and discussion. All patients showed a significant decrease in the adaptational status - the prevalence of stress ARs and tensioned anti-stressor ARs of VLRL and LRL (70-100\%). LC patients in gr. 3 had AR characteristics reflecting the most favorable body status: the development of anti-stressor MRL ARs, as well as AR QI elevated by $1.8-2.7$ times compared to gr. 1 and 2 
Characteristics of adaptational reactions (AR) in patients with lung cancer with various malignant spread

\begin{tabular}{|c|c|c|c|}
\hline Groups & $\mathbf{1}$ & $\mathbf{2}$ & $\mathbf{3}$ \\
\hline AR & $\begin{array}{c}\text { Stress and anti-stressor ARs } \\
\text { of VLRL and LRL }\end{array}$ & $\begin{array}{c}\text { Stress and anti-stressor ARs } \\
\text { of VLRL and LRL }\end{array}$ & $\begin{array}{c}\text { Stress and anti-stressor ARs } \\
\text { of VLRL, LRL and MRL }\end{array}$ \\
\hline QI & $\begin{array}{c}738 \pm 119 \\
n=42\end{array}$ & $\begin{array}{c}487 \pm 126 \\
n=22\end{array}$ & $\begin{array}{c}1305 \pm 113 \\
n=37 \\
\bullet\end{array}$ \\
\hline
\end{tabular}

Note. AR - adaptational reactions, VLRL, LRL, MRL - respectively, "very low", "low" and "moderate" levels of the body reactivity, QI - quantitative indicator, $n-$ number of in the group during the whole treatment period. $\bullet-$ differs from the value in gr. $1, \bullet-$ differs from the value in gr. $2, p<0.01$.

(Table). In patients with similar surgeries, for example with atypical lung resection, AR QI in gr. 3 was notably higher than in gr. $2-$ respectively, $1300 \pm 278$ and $95 \pm 18(p<0.01)$. These results suggested that different AR QI in patients of gr. 2 and 3 were associated with the presence or absence of metastases and not with the surgical volume.

Similar differences in the adaptational status were observed in patients with BPDC. Prior to the surgery, PS gr. showed the prevalence of the lowest QI - stress AR and training AR of VLRL, as well as stress AR of LRL (61\%). Same ARs in RS gr. were almost 3 times less frequent ( $21 \%$ of cases, $p<0.05)$. Stress ARs of VLRL were not observed. Surgery caused a predictable decline in the adaptational status of most patients in all groups $(p<0.05)$. However, despite a greater surgical volume of radical pancreatoduodenal resection compared with bypass anastomosis, AR QI in RS gr. one day after the surgery was markedly higher than in PS gr. $-187 \pm 39$ and $80 \pm 24$, respectively $(p<0.05)$.

Conclusion. The study demonstrated an association between the malignant spread in the lungs and BPD organs and AR characteristics reflecting the state of systemic neuroendocrine and immune mechanisms of the nonspecific antitumor resistance of the body.

\section{References}

1. Garkavi LKh. Activation therapy. Rostov-on-Don. 2006. 256 p. (In Russ.)

2. Selye H. Thymus and adrenals in the response of the organisms to injuries and intoxication. Brit. J. Exp. Path. 1936;17:234-248.

3. Zhukova GV, Shikhlyarova AI, Maschenko NM, et al. Processes in regulatory systems during development of various adaptational reactions and evaluation of functional state dynamics in the organism. Cardiometry. 2015;7:47-57. 